\title{
Antigypsyism as Symbolic and Epistemic Violence in Informative Journalism in Spain, 2010-2018
}

\section{Ismael Cortés Gómez}

ismaelcortes_@hotmail.com

Member of the Congress of Deputies of Spain, Unidas Podemos/En Comú Podem

ORCID: https://orcid.org/0000-0002-1541-7306

Dr. Ismael Cortés is a member of the Spanish parliament. He has been a lecturer at the UNESCO Chair of Philosophy for Peace, Jaume I University, where he gained his $\mathrm{PhD}$ on international conflicts and social development studies with an international award. In 2018, he was a postdoctorate fellow of the Romani Studies Program at the Central European University. Together with Markus End, he edited the book Dimensions of Antigypsyism in Europe (ENAR and Central Council of German Sinti and Roma 2019).

\section{Critical}

Romani Studies 


\section{Abstract}

This study conducts a framing analysis of how Spanish journalism represents "Gypsy identity" within the markers of dangerousness and criminality (in the period from 2010 to 2018). The paper aims to validate the following underpinning hypothesis: as symbolic and epistemic violence, antigypsyism legitimizes systemic racial discrimination and exclusion against Roma in Spain. The article is organized into five sections. First, an analytical framework introduces the notions of "antigypsyism," "structural discrimination," "social fear," "symbolic violence," "epistemic violence," and "framing analysis." Second, a case study is presented on a sample of 150 national news reports that portray Romani characters in a biased way. Third, this analysis informs an ethical and legal debate that challenges the limits of free speech and the uses of discriminatory and biased language in informative narratives. The fourth section examines and provides conclusions regarding the correlation between structural discrimination against Roma and the role of media in engendering the stigma of the "Gypsy threat." Finally, the article includes a series of recommendations that could be used to counteract racism in news narratives.

\section{Keywords}

- Antigypsyism

- Structural discrimination

- Framing analysis

- Symbolic violence

- Epistemic violence

- Social fear

- Journalism 


\section{Introduction}

The ultimate goal of this study is to orient media policies and media practices toward the promotion of nondiscrimination of ethno-racial minorities - and more concretely to the prevention of antigypsyism.

In recent years, the notion of "antigypsyism" has received increasing attention in political and scholarly fields in Europe (Agarin 2014; End and Selling 2015; European Parliament 2015; 2017; Carrera, Rostas, and Vosyliute 2017; 2018, European Union Fundamental Rights Agency 2018; Cortés and End 2019). The following different (and complementary) definitions have been proposed at institutional and civil societal levels:

- Antigypsyism is a specific form of racism, an ideology founded on racial superiority, and a form of dehumanization and institutional racism nurtured by historical discrimination, which is expressed through, among other things, violence, hate speech, exploitation, stigmatization, and the most blatant kind of discrimination (European Commission against Racism and Intolerance 2011).

- Antigypsyism is a specific nature of racism directed towards Roma, on par with anti-Semitism. It is persistent both historically and geographically (permanent and not decreasing), systematic (accepted by virtually all the community), and often accompanied by acts of violence and discrimination (Council of Europe 2012).

- Antigypsyism is a historically constructed, persistent complex of customary racism against social groups identified under the stigma "Gypsy," or other related terms and incorporates. It includes the homogenizing and essentialising perception and description of these groups, the attribution of specific characteristics to them, and discriminating social structures and violent practices that emerge against this background, and which have a degrading and ostracising effect, and reproduce structural disadvantages (Alliance against Antigypsyism 2017).

The fight against antigypsyism is part of a wider fight against racial discrimination. According to the International Convention on the Elimination of All Forms of Racial Discrimination (ICERD):

the term "racial discrimination" shall mean any distinction, exclusion, restriction or preference based on race, colour, descent, or national or ethnic origin, which has the purpose or effect of nullifying or impairing the recognition, enjoyment or exercise, on an equal footing, of human rights and fundamental freedoms, in the political, economic, social, cultural or any other field of public life (ICERD 1965).

According to the EU Race Equality Directive, racial or ethnic discrimination includes the unequal access or treatment of certain groups in areas such as employment, education, security, healthcare, housing, and the supply of goods and services (Directive 2000/43/EC). According to the United Nations Economic and Social Council (ECOSOC), the study of situations of exclusion and discrimination should not only describe a certain state of deprivation of fundamental rights, but should include an analysis of the cultural and economic processes that led to that state and sustain it (ECOSOC 2018). 
Apart from the aforementioned items, urban segregation can also be considered in the fundamental matrix of racial exclusion. Picker (2017) reported that segregated Romani urban areas, which are partially or completely occupied by Romani households, can be observed across Europe. These are regularly marked by higher rates of unemployment than other areas, with few or no public services, substandard housing, low-quality education, unsuitable sanitary infrastructure, and harsh stigmatisation. ${ }^{[1]}$ In Spain, recent studies have reported 2,604 segregated Roma neighbourhoods or settlements corresponding to 1,069 municipalities (Laparra 2011; La Parra-Casado and Jiménez González 2016; Ministerio de Sanidad, Servicios Sociales e Igualdad 2016).

This paper responds to recent studies that have analysed the notions of "discrimination" and "exclusion" related to antigypsyism. Ryder and Taba (2017) focused on the effect of economic intervention and redistribution on diminishing antigypsyism. They recommended active welfare state measures and special efforts for job creation. Rostas (2019) emphasised democratisation and active citizenship. He claims that the rise of Romani ${ }^{[2]}$ political consciousness - that is, Romani participation in public life and the representation of Romani interests in decision-making processes - may be a crucial element in bringing about systemic transformations and eliminating discrimination. On the other hand, Kóczé and Rövid (2019) and End (2019) pointed to the power of media and political discourses to challenge deeprooted anti-Romani prejudices and deconstruct cultural mechanisms of binary othering.

This paper aims to contribute to the theoretical and political critique of antigypsyism by, on the one hand, examining the moral foundations of media representations, and on the other hand, by explaining how systemic relationships of racial discrimination and exclusion are constructed through symbolic and epistemic frameworks. This paper analyses the use of symbolism and knowledge as a core mechanism of antigypsyism. As such, the paper is based on the concepts of "symbolic violence" (Bourdieu 1979) and "epistemic violence" (Spivak and Guha 1988; Spivak 1994). Bourdieu's classical definition of symbolic power is as follows:

The power to construct reality, which tends to establish a gnoseological order, generates the consensus on the sense of a social world, which makes a fundamental contribution toward reproducing the social order; "logical" integration is the precondition of "moral" integration... The dominant culture produces its specific ideological effect by concealing

1 See annexes for data on the situation of anti-Romani discrimination in Spain.

2 As indicated by Petrova, the term "Roma," which is the ethnocultural self-appellation of many of those perceived by outsiders as "Gypsies," dominates the official political discourse and has acquired the legitimacy of political correctness (Petrova 2003). As explained by Hancock (2002), the ethnonym "Gypsy" was mistakenly introduced and used in the United Kingdom between the sixteenth and seventeenth centuries. The then non-Romani population in the UK used the term "Gypsy" based on the misinterpretation that the Romani people came from Egypt. The original endonym used in the Romani language includes "Rom" (man), "Romnj" (woman), and "Roma" (plural generic). In 2012, the European Commission began implementing the European Framework of National Roma Inclusion Strategies and provided the following definition: "the term 'Roma' is used here as well as by a number of international organizations and representatives of Roma groups in Europe, to refer to a number of different groups (e.g., Roma, Sinti, Kale, Gypsies, Romanichels, Boyash, Ashkali, Egyptians, Yenish, Dom, and Lom) and also includes Travellers, without denying the specificities and varieties of lifestyles and situations of these groups" (European Commission 2012). 
its function of division (or distinction) under its function of communication: the culture which unites (a medium of communication), separates (an instrument of distinction) and legitimates distinctions by defining all cultures (designated as sub-cultures) in terms of their distance from the dominant culture (Bourdieu 1979, 79-80).

The original concept of epistemic violence, coined by Spivak, focuses on the colonial subject as follows:

The clearest available example of such epistemic violence is the remotely orchestrated, farflung and heterogeneous project to constitute the colonial subject as Other. This project is also the asymmetrical obliteration of the trace of that Other in its precarious Subjectivity. It is well known that Foucault locates epistemic violence, a complete overhaul of the episteme, in the redefinition of sanity at the end of the European eighteenth century. But what if that particular redefinition was only a part of the narrative of history in Europe as well as in the colonies? What if the two projects of epistemic overhaul worked as dislocated and unacknowledged parts of a vast two-handed engine (Spivak 1994, 76)?

There have been several developments in the concept of epistemic violence (Bartels et al. 2019). In recent studies, epistemic violence has been proposed as applicable to non-colonial subjects (i.e., to any victim of a complex system of domination developed on knowledge/power relationships):

Epistemic violence, that is, violence exerted against or through knowledge, is probably one of the key elements in any process of domination. It is not only through the construction of exploitative economic links or the control of the politico-military apparatuses that domination is accomplished, but also and, I would argue, most importantly, through the construction of epistemic frameworks that legitimise and enshrine those practices of domination (Galván Alvárez 2010, 11).

The concept of "epistemic activism," coined by Medina (2019), is also considerably relevant to our analysis. The multidimensional approach towards the study of racism, employed by Medina, embraces public and private institutions, cognitive contents, and affective engagements and disengagements:

[epistemic activism] refers to the critical activities of denouncing, contesting and resisting the cognitive-affective attitudes and sensibilities (or insensitivities) that facilitate complicity with racial oppression and with racial violence. My analysis pays particular attention to the role that affectivity plays in complicity with racial violence and how affective attitudes can be used in epistemic activism to disrupt complicity and to mobilize people in the fight against racial violence (Medina 2019, 22).

Different postcolonial authors have reported that in the post-apartheid period, and in the resulting globalisation of anti-racist laws, racial discrimination became predominantly symbolic, cultural, and epistemic, thereby (re)articulating social hierarchies, divisions, and inequalities (Bhabha 2011; Mbembe 2017; Carty and Chandra 2018). Therefore, the fight for racial justice must take new forms to (re)develop strategies of universal inclusion. In this fight for equality, new approaches to use symbolic and epistemic power are crucial for transforming unjust or discriminatory social relations. 
This study conducts a framing analysis of how the mainstream media helps forge stereotypes and prejudices of society towards certain ethnic groups labelled as "Gypsies."[3] Popular stereotypes and prejudices gain epistemic authority upon reinforcement through informative journalism. Beyond the semantic analysis, this study examines three primary effects of the misrepresentation of Roma by news narratives: (1) damaging the reputation of a collective subject, (2) creating fear-based public opinion, and (3) legitimising systemic racial discrimination. This article aims to show that these effects originate from the same anti-Romani media coverage across the ideological spectrum of editorial newspapers in Spain.

Informative narratives define the magnitude of social problems, but they also transmit moral judgements about those responsible, inducing certain sentiments and emotions regarding them. Informative narratives, therefore, serve to not only build cognitive frameworks but also construct frames of interpretation (De los Santos et al. 2019). Regarding the content of the news and the way in which it is framed, this article focuses on the social dimension of fear. In the terms analysed here, "fear" is not a feeling that affects an individual subject, at a particular moment of its existence. I study "fear" as a feeling that affects an important part of the population, in a sustained manner over time, as a result of the collective perception of a social problem. On this matter, in the American context, Hurley's studies (2015) are of special interest. He analysed the construction of the fear of crime in television news and discovered a disproportionate coverage in relation to ethnic-racial variables, with the (over)representation of African Americans as aggressors and white Americans as victims. In the post-9/11 European context, Rane $(2014 ; 2019)$ examined how media generated Islamophobia. He highlighted how, for most people, the (long-term, negative) representations of Muslims in the media serve as a primary source of information about Islam. He also suggested the need for a greater dialogue among different ethnic communities, and more educational interaction, to mitigate the prevalence of Islamophobia.

Informative journalism plays a major role in fostering associations and sentiments of social divisions and moral hierarchies; and news reporting constructs the identifying of, and assigning of blame for,

3 As indicated by Matache and Oprea (2019), the words "Gypsy” (in English), “Tigan” (in Romanian), and its variations have been widely acknowledged as offensive, or at the very least, misnomers. The word "Gitano" (in Spanish) should also be included here. The following are definitions from the dictionary of the Real Academia Española (Royal Spanish Academy):

1) Tigan: 1. A person belonging to a group originating in India and that has now spread to almost every European country, living a seminomadic life in some parts; to drown like a Gypsy in shallow water or at shore - that is, to fail, to give up right when one is just about to succeed. 2. Epithet given to a dark-skinned person. 3. Epithet given to a person with bad habits.

2) Gypsy: 1. A member of a travelling group, traditionally living by itinerant trade and fortune telling. Gypsies speak a language (Romany) that is related to Hindi and are believed to have originated in South Asia. 2. A nomadic or free-spirited person. 3. (adjective) (of a business or business person) non-union or unlicensed.

3) Gitano (etymology from "Egyptian," because it was believed that they came from Egypt) 1. (adjective) Referring to a people originally from India, extended by various countries, who largely maintain a nomadic lifestyle and have retained their own physical and cultural features. 2. (adjective) Belonging to or relative to the Gypsies. 3. (adjective) Belonging to the Gypsies, or similar to them. 4. (adjective) caló (belonging to dark skin people) (Romani lexicon). 5. (adjective) cheater, offensive or discriminatory. 6. (adjective) A graceful and skilled person, able to win the will of others, especially in reference to a woman. 7. (adjective) Egyptian (native of Egypt). 8. (noun) Caló (variety of Romani language) (Real Academia Española 2018, author's translation). 
social problems (D’Angelo and Kuypers 2009; Kelsey 2017; Jakobsson and Stiernstedt 2018). In the posttruth era, well-established news corporations have attempted to justify their social values and epistemic authority by making truth claims based on contrasting facts and expert opinions (Halimi and Rimbert 2019). This paper challenges the objectivity and neutrality of informative journalism when representing Romani identity within the symbolic framework of violence and criminality. Methodologically, through a framing analysis, this paper highlights the rhetorical patterns of social fear engendered by news narratives. Kuypers defined news framing as follows:

consciously or unconsciously, [news framing] acts to construct a point of view that encourages the facts of a given situation to be interpreted by others in a particular manner. Frames operate in four key ways: they define problems, diagnose causes, make moral judgments, and suggest remedies. Frames are often found within a narrative account of an issue or event and are generally the central organising idea $(2006,190)$.

\section{Case Study}

My research started with 1,200 news samples from the most prominent national newspapers: El País, ABC, La Razón, and El Mundo. These samples revealed an explicit semantic association between acts of violence and Romani people. The initial sample size was then narrowed to 100 cases that were repeatedly covered by these four media sources (see annexes). Furthermore, 50 of these 100 cases were commonly reported by the five most prominent national TV news programmes: Informativos de TVE, Antena 3 Noticias, Informativos Telecinco, Noticias Cuatro, and La Sexta Noticias (see annexes).

A semantic frame comprising a repertoire of lexicon and images was then extracted. Such a frame is used to define the criminal actor, their motivations, and the context surrounding the crime. In the reported cases, linguistic representation was accompanied by a mise-en-scène aesthetic of cultural distancing comprising four elements: verbal behaviours (e.g., words and accents), personal images (e.g., clothing), social scenarios (e.g., deteriorated and noisy environments), and nonverbal behaviours (e.g., histrionic emotions and gestures). This frame has been indistinctively and repeatedly used by social, liberal, and conservative news editorials. Thus, a monolithic frame shapes public opinion in a biased direction, associating Romani identity with violence and criminality.

The symbolic construction of cultural distance/cultural proximity determines the moral sentiments of group identification. In this regard, the media analysis revealed the following effects of the misrepresentation of Romani characters: on the one hand, inhibiting attitudes of empathy, solidarity, or trust from the majority society towards Roma; and on the other hand, engendering attitudes of fear, hate, or disdain from the majority society towards Roma. 
Table 1. General semantic frame

\begin{tabular}{|c|c|c|c|}
\hline Crime & Lexicon & Images of characters & Social scenario \\
\hline $\begin{array}{l}\text { Murder } \\
\text { (inside the } \\
\text { ghetto) }\end{array}$ & $\begin{array}{l}\text { - Actor: "Gypsy" } \\
\text { clans } \\
\text { - Motive: Revenge }\end{array}$ & $\begin{array}{l}\text { - Affected Romani families } \\
\text { - Elderly women and children crying } \\
\text { - Elderly men as mediators } \\
\text { - Intimacy of Romani families (ordinary life) } \\
\text { - Young Romani men and women claiming revenge }\end{array}$ & $\begin{array}{l}\text { A slum in a segre- } \\
\text { gated, urban area: } \\
\text { noisy, dirty, and } \\
\text { deteriorated }\end{array}$ \\
\hline $\begin{array}{l}\text { Murder } \\
\text { (outside the } \\
\text { ghetto) }\end{array}$ & $\begin{array}{l}\text { - Actor: A “Gypsy" } \\
\text { person } \\
\text { - Motive: Crime of } \\
\text { passion }\end{array}$ & $\begin{array}{l}\text { - Young Romani men as criminals } \\
\text { - A young person as victim } \\
\text { - Police forces } \\
\text { - Non-Roma as witnesses } \\
\text { - Professional life of the victim } \\
\text { - Family of the victim }\end{array}$ & A nightclub \\
\hline $\begin{array}{l}\text { Armed fight } \\
\text { (inside the } \\
\text { ghetto) }\end{array}$ & $\begin{array}{l}\text { - Actor: "Gypsy" } \\
\text { families } \\
\text { - Motive: Revenge }\end{array}$ & $\begin{array}{l}\text { - Affected Romani families } \\
\text { - Elderly women and children crying } \\
\text { - Elderly men as mediators } \\
\text { - Intimacy of Romani families (ordinary life) } \\
\text { - Young Romani men and women claiming revenge }\end{array}$ & $\begin{array}{l}\text { A slum in a segre- } \\
\text { gated, urban area: } \\
\text { noisy, dirty, and } \\
\text { deteriorated }\end{array}$ \\
\hline
\end{tabular}

Table 2. Example 1 of framing analysis

\begin{tabular}{llll} 
& El País, 8/8/2010 & La Razón, 7/8/2010 & ABC, 7/8/2010 \\
\hline Headline & $\begin{array}{l}\text { A man dies shot in front of a } \\
\text { nightclub in Torrejón (a town) }\end{array}$ & $\begin{array}{l}\text { Revenge in the } \\
\text { "Pícar" (name of } \\
\text { the disco) }\end{array}$ & $\begin{array}{l}\text { A young man dies after a shooting at } \\
\text { the exit of a nightclub in Torrejón }\end{array}$ \\
\hline $\begin{array}{l}\text { Description of } \\
\text { the actors and } \\
\text { context }\end{array}$ & $\begin{array}{l}\text { The criminal actors were } \\
\text { "Gypsies" involved in a fight } \\
\text { with the security guards of the } \\
\text { disco. A man, who was not } \\
\text { involved in the fight, died after } \\
\text { being hit by a bullet at the exit } \\
\text { of the disco. }\end{array}$ & $\begin{array}{l}\text { A man was hit by a } \\
\text { "stray" bullet from } \\
\text { a brawl between a } \\
\text { group of "Gypsies" } \\
\text { and the security } \\
\text { guards at the exit of } \\
\text { the disco. }\end{array}$ & $\begin{array}{l}\text { The perpetrators of the shooting were } \\
\text { of "Gypsy" ethnicity and used force } \\
\text { against the security guards of the dis- } \\
\text { co. Eventually the perpetrators shot at } \\
\text { time. The man who died had nothing } \\
\text { to do with the fight. }\end{array}$ \\
\hline
\end{tabular}

Note: The same case was reported by social, liberal, and conservative news editorials (El País 2010; La Razón 2010; ABC 2010).

Table 3. Example 2 of framing analysis

\begin{tabular}{|c|c|c|c|}
\hline & El País, 21/5/2014 & El Mundo, 21/5/2014 & $A B C, 22 / 5 / 2014$ \\
\hline Headline & $\begin{array}{l}\text { Six arrested for a brawl } \\
\text { with guns in Villena (a } \\
\text { town) }\end{array}$ & $\begin{array}{l}\text { Six arrested for their } \\
\text { involvement in a brawl } \\
\text { with guns }\end{array}$ & $\begin{array}{l}\text { Six arrested in Villena for a brawl } \\
\text { with guns between families }\end{array}$ \\
\hline $\begin{array}{l}\text { Description of } \\
\text { the actors and } \\
\text { the social sce- } \\
\text { nario }\end{array}$ & $\begin{array}{l}\text { The six arrested belong to } \\
\text { "Gypsy" families. The alter- } \\
\text { cation happened in the San } \\
\text { Francisco neighbourhood } \\
\text { (a popular "Gypsy ghetto" } \\
\text { in town). }\end{array}$ & $\begin{array}{l}\text { Six people involved in } \\
\text { a brawl between two } \\
\text { "Gypsy" families. The } \\
\text { altercation happened in } \\
\text { the San Francisco neigh- } \\
\text { bourhood. }\end{array}$ & $\begin{array}{l}\text { The six arrested belong to two } \\
\text { adversarial "Gypsy" families. Rel- } \\
\text { atives of the arrested were present } \\
\text { during the altercation. The alterca- } \\
\text { tion happened in the San Francisco } \\
\text { neighbourhood. }\end{array}$ \\
\hline
\end{tabular}

Note: The same case was reported by social, liberal, and conservative news editorials (El País 2014; El Mundo 2014; ABC 2014). 
Table 4. Example 3 of framing analysis

\begin{tabular}{|c|c|c|}
\hline & El Mundo, 2/9/2015 & $A B C, 2 / 9 / 2015$ \\
\hline Headline & $\begin{array}{l}\text { One death and five wounded in a fight } \\
\text { between two clans of "Gypsy" ethnicity in } \\
\text { Mazarrón (a town) }\end{array}$ & $\begin{array}{l}\text { One death and five hospitalised in a } \\
\text { fight between two clans of "Gypsy" } \\
\text { ethnicity in Mazarrón. }\end{array}$ \\
\hline $\begin{array}{l}\text { Description } \\
\text { of the actors } \\
\text { and the social } \\
\text { scenario }\end{array}$ & $\begin{array}{l}\text { The police investigators declared that ev- } \\
\text { erything started in the morning with an } \\
\text { argument between two adversarial fam- } \\
\text { ilies. Hours later, a car intentionally hit } \\
\text { a person in the middle of the street. As a } \\
\text { consequence, relatives of the victim went } \\
\text { to the area where the alleged perpetrators } \\
\text { lived and attacked them, resulting in a large } \\
\text { brawl, with the death of a woman and sev- } \\
\text { eral people injured. }\end{array}$ & $\begin{array}{l}\text { An argument in the morning between } \\
\text { two women caused a massive fight } \\
\text { hours later, in which two "Gypsy" } \\
\text { clans have been implicated. After the } \\
\text { argument, a driver of a car intention- } \\
\text { ally injured a pedestrian. Afterward, } \\
\text { his relatives went to look for the mem- } \\
\text { bers of the other family and provoked } \\
\text { a massive fight, in which one of the } \\
\text { women died and three people were } \\
\text { critically injured. }\end{array}$ \\
\hline
\end{tabular}

Note: The same case was reported by liberal and conservative news editorials (El Mundo 2015; ABC 2015).

\section{Social Scenarios}

The concept of a dichotomous ethnic living space - inside the ghetto (Romani space) versus outside the ghetto (non-Romani space) - is a virtual construct fixated on and promoted by the news. In real life, several non-Romani people and families live in slums in segregated areas, and Roma live all across the urban landscape. The spatial dichotomy has been artificially radicalised in news narratives. In all possible social scenarios, the news reiterates the image of Romani individuals and families living inside the ghetto and implies that young Romani men cross the ghetto to cause trouble in nightclubs.

\section{Images of Characters}

The repertoire of images generates an association between the array of individual crimes and a single collective subject as a virtual author of all.

The news media presented the crimes that were committed in the ghetto as if they were committed by all members of a Romani family and not by an individual or a group of individuals. The virtual construction of the Romani family establishes criminal behaviour as an inherent element of the culture and implies that these violent elements are inherited across generations. The mise-en-scène recreates the ordinary life of the ghetto and portrays violence as an embodiment of the living space of the ethnic group. Moreover, it emphasises young Romani men and women claiming revenge after a killing or a fight. This implies a vicious cycle of violence. The mise-en-scène portrays an endless state of violence: the desperate tears and screams of Romani women and children, despite the efforts of Romani elders for pacification.

For crimes committed outside the ghetto, the images focus less on the perpetrator (characterised as a young "Gypsy" man) and more on the victim, police, and non-Romani witnesses. The images focus on 
non-Romani citizens and authorities, and portray their experience of criminal disruption caused by a "Gypsy agent" acting outside the ghetto. Moreover, the news narratives include testimonies from the victim's family, who discuss their professional lives, and represent the victim as a "normal citizen," as opposed to the "Gypsy evil."

\section{Lexicon}

Apart from the images of different ethnic characters and the virtual construction of social scenarios, the use of a lexicon is crucial in establishing a group identity in the public imaginary. In this case, ethnicity is underlined as "Gypsy" (Gitano in Spanish).

In cases of collective armed fights in the ghetto, the collective "Gypsy" actor is labelled as a "Gypsy family," which emphasises associations among kinship, ethnic belonging, and criminal behaviour.

In cases of murders in the ghetto, the collective "Gypsy" actor is labelled as a "clan," with two primary connotations: (1) In mafia jargon, the word "clan" refers to a criminal group dedicated to selling illegal drugs, money laundering, and/or organised crime; (2) In cultural anthropology, the word "clan" refers to a pre-civilised social organisation - that is, a group with common ancestry, ruled by its own norms apart from the state. ${ }^{[4]}$

In cases of individual murders outside the ghetto, news narratives highlight the ethnicity of the criminal actor as "Gypsy" and provide no other motivation apart from the impulse for violence against a light provocation. Moreover, the narration emphasises the type of behaviour that is apparently "instinctive" and "natural" to a certain ethnicity. In all cases, the lexicon is redundant (that is, irreconcilable) to the radical cultural distance that exists between the "Gypsy" behaviours and the higher morality of the majority society. Thus, news narratives reinforce the dichotomy between the "Gypsy savageness" and the civilisation of the majority society.

\section{Legal and Ethical Framework}

This analysis is constructed within a legal and ethical framework that regulates discriminatory language in news narratives. In a classical liberal debate on free speech, John Stuart Mill (1859) argued for the absolute freedom of opinion and sentiment on all subjects. However, he introduced a limit to free speech, that is, the "harm principle." According to this principle, a speech can be limited if it exhibits a direct and clear violation of rights. Therefore, the core liberal value - commitment to non-interference in the lives of citizens by the state or by other collectives - is sometimes overridden (Riley 2015). Among the possible types of harmful speech mentioned by Mill (1859), including libel, defamation, or insult, hate speech elicits the most concern because it can evolve to inciting violence (Bilgrami 2015).

4 David Sneath. 2016. “Tribe.” In Cambridge Encyclopedia of Anthropology, edited by Felix Stein, et al. Cambridge, UK: University of Cambridge. https://www.anthroencyclopedia.com. 
In the post-Second World War period, the European Convention on Human Rights restricted the use of freedom of expression in Article 10:

\section{Article 10: Freedom of expression}

1. Everyone has the right to freedom of expression. This right shall include freedom to hold opinions and to receive and impart information and ideas without interference by public authority and regardless of frontiers. This article shall not prevent States from requiring the licensing of broadcasting, television or cinema enterprises.

2. The exercise of these freedoms, since it carries with it duties and responsibilities, may be subject to such formalities, conditions, restrictions or penalties as are prescribed by law and are necessary in a democratic society, in the interests of national security, territorial integrity or public safety, for the prevention of disorder or crime, for the protection of health or morals, for the protection of the reputation or rights of others, for preventing the disclosure of information received in confidence, or for maintaining the authority and impartiality of the judiciary (Council of Europe 1950).

The International Covenant on Civil and Political Rights (ICCPR), adopted by the United Nations (UN) in 1966, expresses a stance against the use of discriminatory language and its radical expression as "hate speech," in its Article 20:

Any advocacy of national, racial or religious hatred that constitutes incitement to discrimination, hostility or violence shall be prohibited by law (United Nations 1966).

The rise of decolonisation and globalisation have enabled an exponential increase in the implementation of this legal concept. However, similar to the efforts to counteract "hate speech," the concept of "freedom of expression" has been known worldwide through Article 19 of the ICCPR:

Everyone shall have the right to freedom of expression; this right shall include freedom to seek, receive and impart information and ideas of all kinds, regardless of frontiers, either orally, in writing or in print, in the form of art, or through any other media of his choice (United Nations 1966).

Different approaches, including various ethical codes of conduct and legal measures at national and international levels, have been employed to overcome any contradiction between these two articles of the ICCPR. The international code of journalistic ethics of the UN Educational, Scientific and Cultural Organization (UNESCO) (1978) presents 10 principles, and journalistic information can be produced on the basis of these principles. Principle eight of this code promotes "respect for universal values and diversity of cultures." Moreover, the code advocates the idea of a journalist as an agent of social cohesion, pacific coexistence, and democratic values of tolerance and pluralism. However, this principle is vague and does not prevent the use of discriminatory language against vulnerable groups, including ethnic, cultural, and racial minorities. 
It should be mentioned that the United Nations Committee on the Elimination of Racial Discrimination (CERD), at its 57th session in 2000, recommended the application of measures in order to:

- eradicate any idea of racial or ethnic superiority, racial hatred, and incitement to discrimination and violence against Roma in the media;

- sensitise professionals from all media regarding their responsibility not to spread prejudices, and to be careful when reporting incidents involving individual members of the Roma community in order to avoid making it appear as if communities as a whole are responsible;

- develop educational and media campaigns to educate the public about Roma culture and the importance of building an inclusive society;

- promote and facilitate Roma participation in the media, including newspapers, radio and television programs, and the creation of their own media, as well as training Roma journalists; and

- promote methods of self-control by the media through a code of conduct for media organizations, with the aim of avoiding racist, discriminatory, or biased language.

In its Opinion 02/2013 on the impact of the Framework Decision on the rights of victims of hate crime, including racism and xenophobia, the Fundamental Rights Agency (FRA) recommended a concrete measure to prevent racist discrimination in the media:

Action 19: EU Member States should encourage the media - while respecting freedom of the press - to take self-regulatory measures and ensure that the information and programs they publish or transmit do not contribute to the vulnerability of victims or fostering a climate of hostility towards people who share protected characteristics (Fundamental Rights Agency 2013).

In the case of Spain, the current State Council of Audiovisual Media condemns the fostering of hate, disparaging attitudes, or discrimination for reasons of birth, racial origin, race or ethnicity, gender, religion, nationality, opinion, or any other personal or social circumstance. More concretely, Spain counts on two major documents aimed at orienting media practices to prevent racism. The first document is the Code of Ethics for the Journalistic Profession of the Federation of Associations of Journalists of Spain (FAPE 1993; 2017), which states in its Article 7:

The journalist will take extreme professional zeal to respect the rights of the weakest and most discriminated against. For this reason, it must maintain a special sensitivity in cases of information or opinions that may have discriminatory content or are likely to incite violence or inhuman or degrading practices:

a. It must, therefore, refrain from referring, in a derogatory way or with prejudice to the race, colour, religion, social origin, or sex of a person, or to any disease or disability of physical or mental suffering.

The second relevant document is the Declaration of Principles of the Journalistic Profession by the College of Journalists of Catalonia (Collegi de Periodistes de Catalunya 1992; 2016). It states the duty to: 
Act with special responsibility and rigour in the case of information or opinions with content that may provoke discrimination based on sex, race, belief, or social and cultural extraction, as well as incite the use of violence, avoiding vexatious or harmful expressions or testimonies for the personal condition of individuals and their physical and moral integrity.

The same College of Journalists of Catalonia carried out a detailed analysis of racism in the media. It contains five recommendations:

1. Do not include ethnic group, skin colour, country of origin, religion, or culture if not strictly necessary for the global understanding of the news.

2. It is necessary to avoid generalities, Manicheism, and simplification of information.

3. Negative or sensational information should not be promoted. We must avoid creating conflicts uselessly and dramatizing them. The search for news must be promoted in a positive manner.

4. Equanimity in the sources of information. Versions need to be checked by consulting institutional sources. It is necessary to promote the characteristics of ethnic minorities and take special care in the information referring to countries of origin.

5. Journalistic militancy: towards an enriching multi-interculturality for all and the enhancement of positive information (Giró 2002).

Freedom of speech is also protected by the Spanish Constitution, in Article 20:

I. The following rights are recognised and protected:

a. To freely express and disseminate thoughts, ideas, and opinions through words, writings, or any other means of reproduction.

b. Literary, artistic, scientific, and technical production, and creation.

c. Academic freedom.

d. To communicate or freely receive accurate information by any means of dissemination. The law will regulate the right to the protection of the clause on conscience and professional secrecy in the exercise of these freedoms.

II. The exercise of these rights cannot be restricted by any type of prior censorship (Congreso de los Diputados 1978).

And yet, freedom of speech is limited by the Spanish criminal code, which characterises several criminal offenses related to hate speech:

Article 510.1:

a.i.1. They will be punished with a prison sentence of one to four years and a fine of six to twelve months:

a. Those who publicly encourage, promote, or directly or indirectly incite hatred, hostility, discrimination, or violence against a group, a part thereof, or against a person 
determined by reason of their membership, for racist, anti-Semitic or other reasons related to ideology, religion or beliefs, family situation, the belonging of its members to an ethnic group, race or nation, national origin, sex, or sexual orientation or identity, for reasons of gender, illness, or disability.

b. Those who produce, elaborate, possess for the purpose of distributing, provide access to third parties, distribute, disseminate, or sell written documents or any other kind of material or media that, due to their content, are suitable to encourage, promote, or incite direct or indirectly to hatred, hostility, discrimination, or violence against a group, a part of it, or against a person determined by reason of their belonging to it, for racist, anti-Semitic, or other reasons related to ideology, religion or beliefs, family situation, the belonging of its members to an ethnic group, race or nation, their national origin, sex, or sexual orientation or identity, for reasons of gender, illness, or disability (Criminal Code 2015; Barja de Quiroga 2019).

The Spanish criminal code prohibits the promotion of hatred, violence, or discrimination through any type of speech. This legal prevention was adopted avant la lettre the definition of "hate speech" approved by the European Commission against Racism and Intolerance (ECRI) in its Recommendation 15 on Combating Hate Speech:

hate speech is based on the unjustified assumption that a person or a group of persons are superior to others; it incites acts of violence or discrimination, thus undermining respect for minority groups and damaging social cohesion (European Commission against Racism and Intolerance 2015).

Anti-hate speech measures must be well-founded and not be misused to curb freedom of expression. In informative journalism, the concept of hate speech is an ethical red line of self-censorship. Journalists and editorial teams must understand the factual consequences of news narratives on violent or discriminatory social relations. Furthermore, free speech regulation must be aligned with Article 2 of the Treaty on European Union:

The Union is founded on the values of respect for human dignity, freedom, democracy, equality, the rule of law and respect for human rights, including the rights of persons belonging to minorities. These values are common to the Member States in a society with pluralism, nondiscrimination, tolerance, justice, solidarity and equality (European Union 2007).

Regarding the cases analysed in the previous section, I do not want to imply that any discriminatory framing of members of a certain group is equivalent to hate speech. But I do want to warn about the thin line between a biased coverage of Romani groups or individuals and the harmful effects that can result - that is, creating an intimidating, hostile, degrading, humiliating, and discriminatory environment for Romani people. Editors and journalists should censor output that would cross that line. On the other hand, anti-hate speech legislation is the ultimate regulation of free speech, including freedom of media. 


\section{Conclusions}

The relation of systemic discrimination and exclusion with symbolic violence can be addressed here with three primary theses:

- Symbolism influences the common sense of the general population and ideologies of governance.

- A historically rooted anti-Romani ideology of governance has placed the Roma population at the bottom of the class structure. This ideology has largely caused impoverishment and declining access to economic and social rights, which is evident through the existing segregated living spaces across the urban landscape of Spain.

- This racist ideology of governance would not be morally accepted in contemporary postcolonial Europe without the social fear of the "Gypsy menace," as manifested by the media, and particularly informative journalism.

The deep, unconscious nature of anti-Romani sentiments leads people as well as institutions (such as the media) to reproduce prejudiced attitudes towards Roma and associated groups. Thus, they follow certain inherited symbolic patterns - that is, using discriminatory language without reflecting upon their own biases. Most of the time, this happens without an intentional or strategic thinking behind it. The reproduction of symbolic violence is a response to the mechanics of social and cultural inertia. Epistemic activism, in response to this force of oppression, aims to raise awareness about the unconscious biases embodied in widely accepted demeaning narratives.

Recent studies have revealed a disparity between the high level of "perceived criminality" and the low level of "actual criminality" in Spain. In the last 10 years, criminality has been one of the five most prominent social concerns, alongside unemployment, political corruption, the economic crisis, and terrorism (Departamento de Seguridad Nacional 2016; Caro Cabrera and Navarro Ardoy 2017). Nevertheless, according to the World Bank (2016), Spain has one of the lowest murder rates in the European Union, with Germany, France, and Portugal having higher rates than Spain. Approximately 300 people (out of a total population of 50 million) are murdered every year in Spain - that is, 0.7 out of 100,000 deaths per year.

This fact raises the following question: what provokes such a fearful perception of crime in Spain? In order to address this question, I pose the following arguments: (1) Social fear is not associated with people's actual personal experiences with crime and is related to levels of virtual exposure to crimes reported by media. (2) Social fear is not provoked through the record of actual crimes but through the frequency and intensity of stories of crime published by mass media.

We may ask ourselves: why do Spanish media convey information on crime in this manner? There have been studies showing the low reading rate in Spain, where the purchase of newspapers has become a less popular habit. While in the countries of northern Europe three or four newspapers are sold for every ten inhabitants, in Spain it is barely one (ComScore 2019). Covering violence and criminality increases the interest of news consumers. According to recent polls, this form of content 
is the most read in the written press (Statista 2020). Reporting homicides or armed fights arouses the most interest. Furthermore, these are cases that involve not only a breach of law, but a clear manifestation of antisocial behaviour, in which it is easy to make a moral judgement (Rodríguez Cárcela 2016).

Inciting social fear by associating social blame or social innocence with racial, cultural, or ethnic groups is intentionally manipulative. When crimes are committed by people other than Roma, ethnicity is not referenced in the news narratives. But as shown in the case study, Romani ethnicity is repeatedly highlighted in a pejorative manner. Ethically and legally, the responsibility of crimes should be attributed to the individuals committing these crimes and never to abstract agents, such as races, cultures, or ethnicities. By correlating cultures, races, and ethnicities with the antagonistic markers of good and evil, news narratives contribute to maintaining inherited prejudices that engender moral divisions and social inequalities.

Hiding behind claims of neutrality, objectivity, and expertise, informative journalism reproduces biases such as stereotypes and moral misjudgements. The symbolic construction of a cultural distance shapes moral sentiments of disengagement, which inhibits attitudes of empathy, solidarity, and trust, and engenders attitudes of disdain, fear, and hate. In the case of anti-Romani stigmatisation by news narratives, the dialectic of inclusion/exclusion and identity/difference is highly moralised, classifying people in hierarchies of moral worth and dividing them into different living spaces and social hierarchies.

\section{Recommendations}

Finally, I want to propose some recommendations that could be used to counteract racism (in general) and antigypsyism (in particular), in the field of informative journalism:

- The codes of conduct of the media should prescribe the avoidance of any semantic relationship between ethnicity and crime.

- States, in collaboration with media experts, should provide training to professional journalists on racism, and include an antiracist code of conduct in the curricula for students of journalism.

- States should introduce legislation to guarantee the participation of ethno-racial minorities in media activities at various levels, including content production, editorial decision-making, and supervisory activities. In this way, minority groups could actively contribute to their own representation.

- The media should produce narratives that reflect experiences of peaceful coexistence between different cultures or ethnicities, and success stories of prominent members belonging to minorities who have contributed significantly to the progress of society. 


\section{References}

$A B C$. 2010. "Muere un joven tras un tiroteo a la salida de una discoteca en Torrejón." $A B C, 7$ August.

—. 2014. "Seis detenidos en Villena por una reyerta con armas de fuego entre familias." ABC, 22 May.

. 2015. "Una fallecida y cinco hospitalizados en una pelea entre dos clanes de etnia gitana tras un atropello en Mazarrón." ABC, 2 September.

Agarin, Timofey, ed. 2014. When Stereotype Meets Prejudice: Antiziganism in European Societies. Stuttgart: Ibidem Verlag.

Alliance against Antigypsyism. 2017. Antigypsyism: A Reference Paper. Brussels: Alliance against Antigypsyism.

Barja de Quiroga, Jacobo, and Carlos Granados Pérez. 2019. Código Penal: Código Comentado: Concordancias, Comentarios y Jurisprudencia. La Coruña: Colex.

Bartels, Anke et al. 2019. "Interlude: Epistemic Violence." In Postcolonial Literatures in English, edited by Anke Bartels et al., 153-4 Stuttgart: J. B. Metzler.

Bhabha, Homi K. 2011 Our Neighbours, Ourselves: Contemporary Reflections on Survival. Berlin: Hegel Lectures series/De Gruyter.

Bilgrami, Akeel. 2015. “The Ambitions of Classical Liberalism: Mill on Truth and Liberty." Revue Internationale de Philosophie 272(2): 175-82.

Bourdieu, Pierre. 1979. The Inheritors: French Students and Their Relations to Culture. Chicago, IL: University of Chicago Press.

Caro Cabrera, Manuel, and Luis Navarro Ardoy. 2017. "La medición del miedo al delito a través de los barómetros del CIS.” Reis: Revista Española de Investigaciones Sociológicas 157: 23-44.

Carrera, Sergio, Iulius Rostas, and Lina Vosyliute. 2017. Combating Institutional Anti-Gypsyism: Responses and Promising Practices in the EU and Selected Member States. Brussels: Centre for European Policy Studies.

- 2018 Study on Scaling up Roma Integration Strategies: Truth, Reconciliation, and Justice for Addressing Antigypsyism. Brussels: European Parliament's Policy Department for Citizens' Rights and Constitutional Affairs.

Carty, Linda, and Chandra Talpade Mohanty, eds. 2018. Feminist Freedom Warriors: Genealogies, Justice, Politics, and Hope. Chicago, IL: Haymarket Books.

Collegi de Periodistes de Catalunya. 1992. "Codi Deontològic: Declaració de principis de la professió periodística a Catalunya, va ser proclamat en el II Congrés de la professió,” Barcelona: Collegi de Periodistes de Catalunya.

ComScore. 2019. "Market and Audience Analytics," https://www.comscore.com

Congreso de los Diputados. 1978. Constitución Española. Madrid: Congreso de los Diputados.

Consejo para la Eliminación de la Discriminación Racial o Étnica (CEDRE). 2014. Percepción de la Discriminación por el Origen Racial o Étnico por parte de las Potenciales Víctimas en 2013. Madrid: Ministerio de Sanidad, Servicios Sociales e Igualdad.

Cortés, Ismael, and Markus End, eds. 2019. Dimensions of Contemporary Antigypsyism in Europe. Brussels, Berlin: European Network Against Racism and Zentralrat Deutscher Sinti und Roma. 
Council of Europe (CoE). 2012. "European Convention on Human Rights, signed at Rome on 4 November 1950." Strasbourg: Council of Europe.

_ 2012 “Descriptive Glossary of Terms Relating to Roma Issues." Strasbourg: Council of Europe.

Criminal Code. 2015. “Ley Orgánica 1/2015, de 30 de marzo, por la que se modifica la Ley Orgánica 10/1995, de 23 de noviembre, del Código Penal." Available at https://www.boe.es/eli/es/lo/2015/03/30/1/con

D’Angelo, Paul, and Jim A. Kuypers. 2009. Doing News Framing Analysis: Empirical and Theoretical Perspectives. London: Routledge.

Decade of Roma Inclusion Secretariat Foundation (DRISF). 2013. Civil Society Monitoring Report on the Implementation of the National Roma Integration Strategy on the Implementation of the National Roma Integration Strategy and Decade Action Plan in 2012 in Spain. Budapest, Hungary: Decade of Roma Inclusion Secretariat Foundation.

De la Rica, Sara. 2019. Estudio Comparado Sobre la Situación de la Población Gitana en España en Relación al Empleo y la Pobreza 2018. Madrid: Fundación Secretariado Gitano/Fundación ISEAK.

De los Santos, Theresa M., and Robin L. Nabi. 2019. "Emotionally Charged: Exploring the Role of Emotion in Online News Information Seeking and Processing." Journal of Broadcasting \& Electronic Media 63(1): 39-58.

Departamento de Seguridad Nacional (DSN). 2016. “Estadísticas de Criminalidad en España, 2016." Gabinete de la Presidencia, Gobierno de España.

El Mundo. 2014. “Seis etenidos por su implicación en una reyerta con armas de fuego." El Mundo, 21 May.

- 2015. "Un muerto y cinco heridos en una pelea entre dos clanes de etnia gitana tras un atropello en Mazarrón.” El Mundo, 2 September.

El País. 2010. "Muere un hombre de un balazo frente a una discoteca de Torrejón." El País, 8 August.

-2014. Seis detenidos por una reyerta con armas de fuego en Villena." El País, 21 May.

End, Markus. 2019. "Subtle Images of Antigypsyism: An Analysis of the Visual Perception of 'Roma." In Dimensions of Contemporary Antigypsyism in Europe, edited by I. Cortés and M. End, 67-88. Brussels, Berlin: European Network Against Racism and Zentralrat Deutscher Sinti und Roma.

End, Markus, and Jan Selling, eds. 2015. Antiziganism: What's in a Word? Cambridge, UK: Cambridge Scholars Publishing.

European Anti-Poverty Network. 2019. "El estado de la pobreza: Seguimiento del indicador de pobreza y exclusión social en España 2008-2018.” Madrid: Octubre.

Eurobarometer. 2012. Immigrants and Out-Groups in Western Europe. Report No. 2012-239, Köln, Germany: GESIS Leibniz Institute for the Social Sciences.

Eurobarometer. 2019. "Discrimination in the EU." Brussels: European Commission.

https://ec.europa.eu/commfrontoffice/publicopinion/index.cfm/Survey/getSurveyDetail/instruments/SPECIAL/ surveyKy/2251

European Commission. 2012. "Communication from the Commission to the European Parliament, the Council, the European Economic and Social Committee and the Committee of the Regions. National Roma Integration Strategies: A First Step in the Implementation of the European Union Framework." 21.5.2012. COM (2012) 226 final. Brussels: European Commission. 
European Commission against Racism and Intolerance (ECRI). 2011. "General Policy Recommendation No. 13 on Combating Anti-Gypsyism and Discrimination and Roma, adopted at Strasbourg on 24 June 2011." Strasbourg: European Commission against Racism and Intolerance.

. 2015. "General Policy Recommendation n.15 on Combating Hate Speech, adopted at Strasbourg on 8 December 2015." Strasbourg: European Commission against Racism and Intolerance.

European Parliament. 2015. "European Parliament Resolution of 15 April 2015 on the Occasion of International Roma Day Anti-Gypsyism in Europe and EU Recognition of the Memorial Day of the Roma Genocide during World War II." Brussels: European Parliament.

_. 2017. "European Parliament Resolution of 25 October 2017 on Fundamental Rights Aspects in Roma Integration in the European Union: Fighting Anti-Gypsyism.” Brussels: European Parliament.

European Union. 2000. "Race Equality Directive, Council Directive 2000/43/EC of 29 June 2000 Implementing the Principle of Equal Treatment between Persons Irrespective of Racial or Ethnic Origin.” Brussels: European Union.

- 2007. "Treaty of Lisbon amending the Treaty on European Union and the Treaty Establishing the European Community, signed in Lisbon on 13 December 2007.” Brussels: European Union.

European Union Fundamental Rights Agency (FRA). 2013. “Opinion of the European Union Agency for Fundamental Rights on the Framework Decision on Racism and Xenophobia - with Special Attention to the Rights of Victims of Crime, Vienna 15 October 2013.” Brussels: European Union Fundamental Rights Agency.

_ 2016. EU MIDIS II "Second European Union Minorities and Discrimination Survey Roma - Selected Findings.” Brussels: European Union Fundamental Rights Agency.

_. 2018. "A Persisting Concern: Anti-Gypsyism as a Barrier to Roma Inclusion." Brussels: European Union Fundamental Rights Agency.

Federación de Asociaciones de Periodistas de España (FAPE). 1993. "Código Deontológico. Aprobado en Asamblea Ordinaria celebrada en Sevilla el día 27 de Noviembre de 1993 y actualizado en Asamblea Ordinaria celebrada en Mérida el día 22 de abril de 2017.” Madrid: Federación de Asociaciones de Periodistas de España.

Galván-Álvarez, Enrique 2010. "Epistemic Violence and Retaliation: The Issue of Knowledges in Mother India. Atlantis 32(2): 11-26.

Giró, Xavier. 2002. “Comentaris sobre el Manual d’estil periodístic relatiu a minories ètniques i noves propostes," Quaderns del CAC 12: 13-24.

Halimi, Serge, and Pierre Rimbert. 2019. “The Media and the Mueller Report.” Le monde diplomatique, May.

Hancock, Ian. 2002. We Are the Romani People, Ame sam e Rromane dzene. Hatfield: Centre de recherches tsiganes/ University of Hertfordshire Press.

Hurley, Ryan J., Jakob Jensen, Andrew Weaver, and Travis Dixon. 2015. "Viewer Ethnicity Matters: Black Crime in TV News and Its Impact on Decisions Regarding Public Policy." Journal of Social Issues 71(1): 155-70.

Jakobsson, Peter, and Fredrik Stiernstedt. 2018. "Voice, Silence and Social Class on Television." European Journal of Communication 33(5): 522-39.

Kelsey, Darren. 2017. Media and Affective Mythologies: Discourse, Archetypes and Ideology in Contemporary Politics. London, UK: Palgrave Macmillan.

Kóczé, Angéla, and Márton Rövid. 2019. “The Europeanisation of Racial Neoliberalism: The Case of 'Roma’ and 'Refugees.”' In Dimensions of Contemporary Antigypsyism in Europe, edited by Ismael Cortés and Markus End, 107-23. Brussels, Berlin: European Network Against Racism and Zentralrat Deutscher Sinti und Roma. 
Kovats, Martin, and Ian Law. 2018. Rethinking Roma - Identities: Politicisation and New Agendas. London, UK: Palgrave Macmillan.

Kuypers, Jim A. 2006. Bush's War: Media Bias and Justifications for War in a Terrorist Age. Washington, D.C.: Rowman and Littlefield Publishers.

La Parra-Casado, Daniel, and Nicolás Jiménez González. 2016. Sastipen aj Rroma: Desigualdad en salud y comunidad gitana. Alicante: Universidad de Alicante.

Laparra, Miguel et al. 2011. Diagnóstico social de la comunidad gitana en España: Un análisis contrastado de la Encuesta del CIS a Hogares de Población Gitana 2007. Madrid: Ministerio de Sanidad, Política Social e Igualdad.

La Razón. 2010. “Venganza en la 'Pícaro.” La Razón, 7 August.

Matache, Margareta, and Alexandra Oprea. 2019. "Reclaiming the Narrative: A Critical Assessment of Terminology in the Fight for Roma Rights." In Dimensions of Contemporary Antigypsyism in Europe, edited by Ismael Cortés and Markus End, 276-300. Brussels, Berlin: European Network Against Racism and Zentralrat Deutscher Sinti und Roma.

Mbembe, Achille. 2017. Critique of Black Reason. Durham, NC: Duke University Press.

Medina, José. 2019. “Racial Violence, Emotional Friction, and Epistemic Activism.” Angelaki: Journal of Theoretical Humanities 24(4): 22-37.

Mill, John Stuart. 1859. On Liberty. London: John W. Parker and Son.

Ministerio de Sanidad, Servicios Sociales e Igualdad. 2016. "Estudio-Mapa sobre Vivienda y Población Gitana, 2015." Madrid: Ministerio de Sanidad.

Petrova, Dimitrina. 2003. “The Roma: Between a Myth and the Future." Social Research 70: 111-61.

Picker, Giovanni. 2017 Racial Cities: Governance and the Segregation of Romani People in Urban Europe. London, UK: Routledge.

Rane, Halim et al. 2014. Media Framing of the Muslim World: Conflicts, Crises and Contexts. London, UK: Palgrave Macmillan.

. 2019. Islam and Muslims in the West. Major Issues and Debates. London, UK: Palgrave Macmillan.

Real Academia Española. 2018. Diccionario de la lengua Española. https://dle.rae.es

Riley, Jonathan. 2015. The Routledge Philosophy Guidebook to Mill's on Liberty. New York: Routledge.

Ryder, Andrew, and Marius Taba. 2018. "Roma and a Social Europe: The Role of Redistribution, Intervention and Emancipatory Politics." Journal of Poverty and Social Justice 26(1): 59-75.

Rodríguez Cárcela, Rosa. 2016. “La prensa de sucesos en el Periodismo español." Revista internacional de Historia de la Comunicación 6: 22-44.

Rostas, Iulius. 2019. A Task for Sisyphus: Why Europe’s Roma Policies Fail. Budapest: Central European University.

Sneath, David. 2016. “Tribe." In Cambridge Encyclopedia of Anthropology, edited by Felix Stein et al. Cambridge, UK: University of Cambridge. https://www.anthroencyclopedia.com.

Spivak, Gayatri Chakravorty. 1994. “Can the Subaltern Speak?” In Colonial Discourse and Post-colonial Theory, edited by Patrick Williams and Laura Chrisman, 66-111. New York: Columbia University Press.

Spivak, Gayatri Chakravorty, and Ramachandra Guha. 1988. Selected Subaltern Studies. Oxford, UK: Oxford University Press. 
Statista. 2020. “Estadísticas y datos de mercado sobre los medios de comunicación." Statista. https://es.statista.com/sectores/1178/medios-de-comunicacion-y-marketing

United Nations Education, Science, and Cultural Organization (UNESCO). 1978. “Declaration on Fundamental Principles concerning the Contribution of the Mass Media to Strengthening Peace and International Understanding, to the Promotion of Human Rights and to Countering Racialism, Apartheid and Incitement to War." Paris: UNESCO.

United Nations (UN). 1965. "International Convention on the Elimination of All Forms of Racial Discrimination." Adopted by the United Nations General Assembly. Resolution 2106 (XX). New York: United Nations.

. 1966. "International Covenant on Civil and Political Rights (ICCPR).” Adopted by the United Nations General Assembly on 16 December 1966. Resolution 2200A (XXI). New York: United Nations.

_ 2018 "Promoting Inclusion through Social Protection." Report on the World Social Situation. New York: United Nations.

World Bank (WB). 2016. Intentional Homicides (per 100,000 People): Global Trends 2010/16. Washington DC: World Bank. 